\begin{tabular}{|l|l|l||}
\hline \multicolumn{2}{|c|}{ PublisherInfo } \\
\hline \hline PublisherName & $:$ & BioMed Central \\
\hline \hline PublisherLocation & $:$ & London \\
\hline \hline PublisherImprintName & $:$ & BioMed Central \\
\hline \hline
\end{tabular}

\title{
Inhibition of IL-1? activity using IL-1RII
}

\begin{tabular}{||l|l|l||}
\hline \multicolumn{2}{|c|}{ ArticleInfo } \\
\hline \hline ArticleID & $:$ & 271 \\
\hline \hline ArticleDOI & $:$ & $10.1186 /$ ar-2002-76204 \\
\hline \hline ArticleCitationID & $:$ & 76204 \\
\hline \hline ArticleSequenceNumber & $:$ & 24 \\
\hline \hline ArticleCategory & $:$ & Paper Report \\
\hline \hline ArticleFirstPage & $:$ & 1 \\
\hline \hline ArticleLastPage & $:$ & 3 \\
\hline \hline & & RegistrationDate : 2002-3-13 \\
& $:$ & Received \\
ArticleHistory & & Accepted 2002-3-13 \\
& $: 2002-3-18$ \\
\hline \hline ArticleCopyright & $:$ & Biomed Central Ltd2002 \\
\hline \hline ArticleGrants & $:$ & \\
\hline \hline
\end{tabular}




\begin{tabular}{|l|l|l|}
\hline ArticleContext & $:$ & 130754411 \\
\hline
\end{tabular}

\section{Cheryl Smythe, ${ }^{\text {Aff1 }}$}

Aff1 Imperial College Faculty of Medicine, London, UK

\section{Keywords}

adenovirus, chondrocyte, IL-1RII, IL-1?, nitric oxide, osteoarthritis, PGE2, synoviocyte

\section{Context}

Interleukin-1? (IL-1?) is constitutively produced in osteoarthritis(OA)-affected cartilage and plays a key role in the pathogenesis of the disease by inducing and maintaining an imbalance of cartilage homeostasis and extracellular matrix synthesis. In normal and OA-affected human cartilage, expression of innate antagonist regulators of IL-1 is deficient. Therefore, inhibition of IL-1? action using the IL-1? type II receptor (IL-1RII), which acts as a decoy receptor, would have therapeutic potential. Indeed, IL-1?-induced nitric oxide (NO) and prostaglandin $\mathrm{E}_{2}\left(\mathrm{PGE}_{2}\right)$ production by chondrocytes, synoviocytes and epithelial cells has been shown to be significantly inhibited by soluble IL-1RII. In this study, the authors have further examined the effects of reconstituting IL-1RII deficient (IL-1RII') cells with IL-1RII using adenoviral gene transfer.

\section{Significant findings}

IL-1? mRNA and protein expression is 10 -fold greater in OA than normal cartilage. IL-1RII ${ }^{+}$cells expressed significant amounts of both intracellular and secreted IL-1RII. IL-1?-induced PGE2 secretion was inhibited in IL-1RII ${ }^{+}$chondrocytes and OA synoviocytes compared to untransfected controls. IL-1?-induced IL-6 and IL-8 production and tumour necrosis factor (TNF)-a-induced PGE2 production in IL-1RII ${ }^{+}$A549 human epithelial cells was inhibited. Induction of IL-1? mRNA by IL-1? was also inhibited in these cells. Membrane bound IL-1RII was shown to block IL-1? activity more effectively than soluble (s)IL-1RII. OA-affected cartilage incubated with IL-1RII ${ }^{+}$synovial cells, but separated by a buoyant chamber insert, showed reduced levels of spontaneous and IL-1?-induced $\mathrm{PGE}_{2}$ and NO production. Furthermore the IL-1?-mediated reduction in proteoglycan synthesis was reversed by paracrine sIL-1RII. Human OA-affected cartilage was used to generate IL-1RII ${ }^{-}$and IL-1 RII ${ }^{+}$ 
chondrocytes that were then transplanted onto the autologous cartilage. OA-affected cartilage transplanted with human IL-1R $\mathrm{II}^{+}$chondrocytes showed inhibition of spontaneous and exogenous IL-1?-induced NO, PGE2, IL-6 and IL-8 production and a reversal of IL-1?-mediated reduction in proteoglycan production; controls transplanted with IL-1RII' cells showed none of these effects.

\section{Comments}

This study is an extension of the group's earlier work that demonstrated that IL-1?-induced NO and $\mathrm{PGE}_{2}$ production by chondrocytes, synoviocytes and epithelial cells is inhibited by soluble IL-1RII (see Additional information). These publications implicate the therapeutic use of IL-1RII in the treatment of OA. The current study identifies the paracrine action of transgenic IL-1RII, which would allow transduced synovial cells to also inhibit IL-1?-mediated events in nearby cartilage. However the evaluation of transgenic IL-1RII expression in an animal model of OA now needs to be carried out.

\section{Methods}

Chondrocyte isolation, culture and transplantation, synovial cell isolation, recombinant adenovirus construction, immunostaining, RT-PCR and real-time PCR, assays for $\mathrm{PGE}_{2}$, nitrite and proteoglycan synthesis

\section{Additional information}

Attur MG, Dave M, Cipolletta C, Kang P, Goldring MB, Patel IR, Abramson SB, Amin AR:

Reversal of autocrine and paracrine effects of interleukin 1 (IL-1) in human arthritis by type II IL-1 decoy receptor. Potential for pharmacological intervention. J Biol Chem 2001, 275:40307-40312 (Paper\%20report).

\section{References}

1. Attur MG, Dave MN, Leung MY, Cipolletta C, Meseck M, Woo SLC, Amin AR: Functional genomic analysis of type II IL-1? decoy receptor: potential for gene therapy in human arthritis and inflammation. J Immunol. 2002, 168: 2001-2010.

This PDF file was created after publication. 